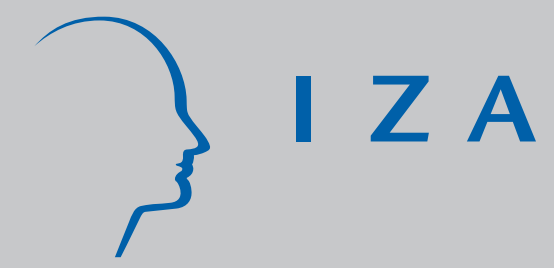

IZA DP No. 80

The Netherlands:

Old Emigrants - Young Immigrant Country

J an C. van Ours

J ustus Veenman

December 1999 


\title{
The Netherlands: Old Emigrants - Young Immigrant Country
}

\author{
Jan C. van Ours \\ Department of Economics, Tilburg University, CentER, \\ Institute for Labour Studies (OSA), and CEPR \\ Justus Veenman \\ Department of Economics, Erasmus University Rotterdam, \\ Institute for Sociological and Economic Research (ISEO) and Tinbergen Institute \\ Discussion Paper No. 80 \\ December 1999 \\ IZA \\ P.O. Box 7240 \\ D-53072 Bonn \\ Germany \\ Tel.: +49-228-3894-0 \\ Fax: +49-228-3894-210 \\ Email: iza@iza.org
}

This Discussion Paper is issued within the framework of IZA's research area Mobility and Flexibility of Labor Markets. Any opinions expressed here are those of the author(s) and not those of the institute. Research disseminated by IZA may include views on policy, but the institute itself takes no institutional policy positions.

The Institute for the Study of Labor (IZA) in Bonn is a local and virtual international research center and a place of communication between science, politics and business. IZA is an independent, nonprofit limited liability company (Gesellschaft mit beschränkter Haftung) supported by the Deutsche Post AG. The center is associated with the University of Bonn and offers a stimulating research environment through its research networks, research support, and visitors and doctoral programs. IZA engages in (i) original and internationally competitive research in all fields of labor economics, (ii) development of policy concepts, and (iii) dissemination of research results and concepts to the interested public. The current research program deals with (1) mobility and flexibility of labor markets, (2) internationalization of labor markets and European integration, (3) the welfare state and labor markets, (4) labor markets in transition, (5) the future of work, (6) project evaluation and (7) general labor economics.

IZA Discussion Papers often represent preliminary work and are circulated to encourage discussion. Citation of such a paper should account for its provisional character. 
IZA Discussion Paper No. 80

December 1999

\section{ABSTRACT}

\section{The Netherlands: Old Emigrants - Young Immigrant Country}

Since the mid 1960s the Netherlands has an immigration surplus, mainly because of manpower recruitment from Turkey and Morocco and because of immigration from the former Dutch colony of Surinam. Immigrant workers have a weak labour market position, which is mainly related to their educational level and language skills. Children and grandchildren of immigrants are expected to have better chances to integrate into Dutch society. Nevertheless, specific policy measures are needed to avoid social exclusion of current immigrant workers.

JEL Classification: J15, J61

Keywords: Immigration, ethnic minorities, immigrant workers

Jan C. van Ours

Department of Economics

Tilburg University

P.O. Box 90501

5000 LE Tilburg

The Netherlands

Email: vanours@kub.nl

"This paper was presented at the conference on "European Migration: What Do We Know?" München $14 / 15$ November 1997. The authors thank the participants of this conference for critical remarks on a previous version of the paper. 


\section{INTRODUCTION}

In the course of the twentieth century the Netherlands changed from an emigrant to an immigrant country. After the Second World War in terms of immigration there are three distinct periods in time. The first period is characterised by the de-colonisation of Indonesia, as a consequence of which Moluccans and Dutch-Indonesian people came to the Netherlands. The second period is that of manpower recruitment, during which mainly Turks and Moroccans arrived. In this period the independence of Surinam also caused a large immigration. The final period is the period where immigration is mainly connected to family re-unification and to (political) refugees and asylum seekers.

Now, at the end of the twentieth century about 1.5 million people live in the Netherlands, who by their own birthplace or that of at least one of their parents are considered to be immigrants. Altogether, they comprise about $10 \%$ of the Dutch population. As counted in 1996 the largest groups of immigrants are the Surinamese (280,000), the Turks $(270,000)$, the Moroccans $(225,000)$, the Antilleans $(95,000)$ and the Yugoslavians $(55,000)$. Those from the southern European countries comprise about 85,000 people, who have different nationalities. Even more diversity of nationality is found among the political refugees, who comprise about 150,000 persons. As far as immigrants are concerned we focus on Turks, Moroccans, Surinamese and Antilleans.

On average, the labour market position of immigrant workers is not as strong as that of native Dutch workers. The immigration of the past decades originates from two rather different processes. The de-colonisation caused peaks in immigration in specific years while the hiring of immigrant workers - because of cyclical labour shortages - turned out to have a structural character. Current labour market problems are to some extent related to the shift in immigration from a business cycle phenomenon to a structural process. In the 1960s immigrant workers were hired because the Dutch labour market was booming. The immigrant workers got jobs in industries with low paid labour. Since these industries were 
particularly hit by the economic recession of the 1980s, many immigrant workers lost their jobs to become long term unemployed.

After a period of high unemployment in the early 1980s and a mild decline in the late 1980s, the Netherlands is among the few European countries that experienced a rapid decline of unemployment in the past few years. Whereas in the beginning of the 1990s (registered) unemployment rate went up from 5.9\% in 1990 to $7.0 \%$ in 1995, it went down in recent years, to $4.0 \%$ in 1998 . As we will describe in more detail below unemployment rates of immigrant workers went down as well. However, since the level of the unemployment rates of immigrant workers is far above that of native Dutch workers, we think that there is still need for specific labour market policies with a focus on immigrant workers.

In this paper we give an overview of migration with a focus on immigration. We discuss immigration policy, the socio-economic position of immigrants, the consequences of immigration for the Dutch labour market and labour market policy. The paper is set up as follows. In section 2 we give the stylised facts of population growth, migration and migration policies. In section 3 we describe the labour market position of immigrants in terms of education, earnings, employment, unemployment and mobility. In section 4 we discuss immigration policy, the economic effects of immigration and integration policies. Due to changing circumstances the focus of government policy has changed substantially over time. Section 5 concludes.

\section{MIGRATION: STYLISED FACTS}

\subsection{Population growth and migration (1900-1995)}

To put migration in perspective with respect to the population growth in the Netherlands we first discuss the evolution of the birth surplus. Table 1 presents an overview of population 
growth and migration in the Netherlands in the twentieth century. We distinguish four subperiods. The first period, pre Second World War, has about the same annual number of births of approximately 175,000 as the last period, from 1976 onwards. The second period, from the end of the Second World War to the mid sixties, has the highest annual number of births, with 240,000 about 35\% higher than the amount of the first and the last period. The period from mid sixties to mid seventies has an annual number of births of 225,000. With respect to the annual number of deaths there is not much change over time. Before the Second World War this number is smaller than thereafter, but this has to do with the much smaller population.

The annual birth surplus in the first decades after the Second World War is more than twice as high as the annual birth surplus before the war. After that, the birth surplus declines rapidly until in the last two decades it is just a little less than $40 \%$ of the post war decades. Figure 1 illustrates the evolution of the annual birth surplus over the century. There are clearly two dips during both world wars and there is a definite post second World War baby boom in 1946. Probably the most striking elements of Figure 1 are the sudden major changes in the birth surpluses with a quite constant level before and after the change. The birth surplus before and after the Second World War is constant, but with a big difference in level. The high birth surplus of the 1950s and 1960s changes in a few years to a substantial lower level in the second half of the 1970s, the 1980s and the 1990s.

With respect to immigration Table 1 shows that over time there is a gradual increase, while for emigration after the Second World War there is a steady level of about 60,000 per year. This combination causes the annual emigration surplus of 7,000 in the first decades after the Second World War to turn into an annual immigration surplus of 35,000 in the past two decades.

All in all, the demographic developments have caused the Dutch population growth to decrease from about 150,000 per year after the Second World War to about 100,000 per year in the past decades. Whereas the first number is fully due to a net birth surplus, $35 \%$ of 
the latter number is due to an immigration surplus.

Migration within the Netherlands is somewhat higher after the Second World War than it was before, and substantially higher from the mid sixties onward. Since then every year an average of about 600,000 families move from one municipality to the other.

\subsection{Dutch colonies independent (1946-1963)}

Like many other European countries the Netherlands looses part of its colonies in the decades after the Second World War. In 1946, a first wave of about 70,000 immigrants comes from Indonesia to the Netherlands, followed by a somewhat smaller second wave of 60,000 in 1950 after Indonesia became independent. A third wave of 40,000 immigrants comes from Indonesia after this country nationalised its firms, many of which where until then owned by Dutchmen. Apart from Dutch people returning to the Netherlands, there are also many indigenous people from the colony, especially Moluccans who served in the Dutch colonial army and who leave their home country. Figure 3 shows the evolution of the immigration from Indonesia over time.

\subsection{Manpower Recruitment (1964-1975)}

After a period of modest economic growth in the 1950s, the Dutch economy booms in the 1960s causing shortages in the labour market. The policy of the Dutch government and Dutch employers is to recruit workers from Mediterranean countries, especially Morocco and Turkey. Figure 4 shows the evolution of the immigration from these two countries. Heijke (1986 and 1987a) estimated an immigration equation on the basis of a cross section of countries for the year 1974. He finds that immigration is positively influenced by the size of employment in the country of destination, the size of the population between 15 and 65 years in the country of origin, and the difference in income per head between the country of origin and the country of destination. The geographical distance between the country of origin and the country of destination negatively influences immigration. According to 
Heijke in the 1960s it was hard to fill vacancies for unskilled workers due to the expansion of the Dutch economy. Heijke (1986 and 1987a) presents the results of a cross-section regression for Dutch industries in the year 1975. He finds that the percentage of immigrant workers from Mediterranean countries was higher in industries with a lower growth rate, and a higher percentage of unskilled workers, noisy working conditions and irregular working hours. So, immigrants are concentrated in low growth industries and have jobs with disamenities. As shown in Figure 3, in 1975 there is also a large immigration of about 40,000 people from Surinam, which became independent from the Netherlands in that year.

\subsection{Chain migration and asylum seekers (1976-1997)}

Since the mid 1970s immigration is characterised by an additional inflow of people from Surinam in 1979-80 and people coming from Morocco and Turkey. Family re-unification and family-formation more and more determine the latter immigration. From Figure 4 it appears that there is a big decline of immigration from Morocco and Turkey in the early 1980s and an increase afterwards. The dip in immigration from these countries coincides completely with a sharp increase in Dutch unemployment in the early 1980s and a decrease in the second half of the 1980s. A recent phenomenon is the inflow of (political) refugees and asylum seekers.

\subsection{Evaluation}

In the first decades after the Second World War there is roughly a balance between immigration and emigration despite of the large inflow of Dutch and (Dutch-)Indonesian people coming from Indonesia. Since early 1960s there is an immigration surplus, mainly because of manpower recruitment in Mediterranean countries, people immigrating because of the independence of Surinam, and later on family re-unification/formation. Part of the immigration is caused by external shocks. This also applies to the present immigration of political refugees. Part of the immigration is due to explicit policy because of labour market 
shortages in the 1960s.

There have been a few attempts to explain immigration and emigration using time series information on an aggregate level. Hartog and Vriend (1989) use annual data from the period 1948-79 and find that emigration is negatively influenced by the real national income per head. Heijke (1987b) did a similar time series analysis for the period 1948-1985. He finds that the per capita net national product negatively influences emigration flows from the Netherlands. Hartog and Vriend (1989) find that immigration is affected negatively by the Dutch unemployment rate and positively by the real national income per head. So, there is a clear indication of economic variables driving emigration and immigration. The inflow of immigrant workers in the 1960s at the time was considered to be temporary. Of the first immigration wave (1960-1967) annually about 30 per cent of the immigrant workers residing in the Netherlands returned. In the period 1967-72 this return migration percentage fell to 15 per cent, and thereafter there was hardly any return migration (Hartog and Vriend (1989)). Employers were actively recruiting immigrant workers, especially to fill vacancies for unskilled jobs. According to Hartog and Vriend (1989) hiring immigrant workers was a rational short-run strategy of Dutch employers, since it was much cheaper than paying higher wages for unskilled work to increase labour market participation.

\section{IMMIGRANTS IN THE DUTCH LABOUR MARKET}

\subsection{Recent development in the Dutch labour market}

Since the mid of the 1990s unemployment in Europe is slowly declining. The Netherlands is among the few European countries that experienced a rapid decline of unemployment in the past few years. As Table 2 shows the registered unemployment rate went down from $7.0 \%$ 
in 1995 to $4.0 \%$ in 1998. Another frequently used indicator to characterise the usage of labour is the non-employment rate, the share of the population that has a job. Whereas the unemployment rate is sensitive to government influence with respect to the classification of non-employed, the non-employment rate is not. The average non-employment rate in the Netherlands went down from $42.2 \%$ in 1995 to $39.4 \%$ in 1997. Although there are differences between males and females, the general pattern in the recent developments is the same. For males unemployment went down from $6.4 \%$ in 1995 to $3.5 \%$ in 1998, for females these numbers are $8.1 \%$ and $4.7 \%$ respectively. The non-employment rate of males went down from $28.4 \%$ in 1995 to $26.2 \%$ in 1997, for females the decline was from $56.5 \%$ in 1995 to $53.0 \%$ in 1997.

Nickell and Van Ours (1999) indicate that the improvement of the labour market in the Netherlands originates from general policy measures and macroeconomic events. Firstly, unions in the Netherlands have been very co-operative and they operate within a highly co-ordinated wage bargaining system. Secondly, the Dutch labour market is characterised by a large number of part-time jobs. These part-time jobs allow flexibility for both employers and employees and have enabled a rapid build up of female employment. Thirdly, the gradual restructuring of the benefit system in the Netherlands has helped to reduce unemployment. In the course of the 1980s and 1990s benefits have been reduced and work test has been made stricter. As a complement to this active labour market policies targeted on the long-term unemployed have been introduced.

Not for every group the labour market position is well enough to rely on general policy measures. We think that for immigrant workers there is sufficient reason for specific policy measures. In the section below we describe the position of immigrant workers in the Dutch labour market. Most of our data are from a 1994 labour market survey. Although this survey describes a labour market that substantially improved in recent years we think that the survey we use gives a clear idea of the structural labour market position of immigrant workers relative to native Dutch workers. 


\subsection{Education}

To compare the educational achievements of immigrants and native Dutch, one can use several indicators: from examination performances in primary education, to the age at the end of this education, to the dropout rates in secondary education. All of these indicators give the same answer to the question whether immigrants have educational achievements equivalent to those of the native Dutch. The answer is in the negative. We shall use the two strongest indicators as an example; the educational qualifications of the total populations (15-65 years), and the educational attainment of young people who are still at school.

Recent research data (1994) on the educational qualifications of different ethnic groups demonstrates that Turks and Moroccans are the most disadvantaged. Fully 80 percent of Moroccans only have primary education or less (50 percent have had no formal education); about 70 percent of Turks only have primary education (more than 25 percent have no education). Thirty-six percent of the Surinamese, 30 percent of the Moluccans, and 27 percent of the Antilleans only have primary education, compared with 22 percent of the native Dutch. Thus, although the Caribbean groups have higher educational qualifications than the Turks and Moroccans, they still lag behind the native Dutch. Almost half of the Dutch have at least a senior secondary education diploma, compared with 29 percent of Surinamese and 18 percent of Moluccans. The educational levels of Antilleans most closely approximate to Dutch education levels, although only 39 percent have at least a senior secondary education diploma. In each minority group women lag behind men as far as educational achievements are concerned. A higher percentage of women are on the lower educational levels, a lower percentage on the higher levels although the differences are small among the Antilleans. They show more equality among men and women, just as among the native Dutch.

Given the majority in numbers that the first generation has in most of the immigrant groups, the aforementioned figures especially concern this generation, in 
particular the older people. This makes it interesting to describe the educational attainment of young people separately (Table 3).

The educational levels of young people are higher than those of their parents. This is true of all groups including natives. It does not alter the fact that minority youths still lag behind their native peers. Neither does it change the pattern: Antilleans most closely approximate to Dutch education levels while the Turks and Moroccans are the most disadvantaged. Again, women lag behind men in all minority groups, with the greatest differences among the Surinamese and Antilleans.

Empirical research shows that several factors are of special significance in explaining differences in educational achievements. These factors are migration characteristics, socio-economic status, cultural aspects, and school factors. Migration characteristics are connected with language problems of immigrants, their restricted knowledge of Dutch society in general and the formal educational system in particular, and also with the moment an individual arrives in the Netherlands. Young people, who do not participate in the Dutch educational system from the first year on, appear to have a difficult time "catching up" at school. Many of them also have great difficulty in acquiring the Dutch language, which obstructs learning.

But even those immigrants who speak Dutch well and are familiar with the school system still tend to lag behind the native Dutch. And, even minority children with good language skills, who enrol in the Dutch educational system early, perform less well at school than native Dutch children of the same age, gender, and social class (Martens, Roelandt and Veenman, 1991). So it would appear that, while social class is a very important factor in determining school achievements, cultural aspects probably also contribute to lower performance among minority children. Finally, there are strong indications that many schools are not really effective in combating the educational arrears of minority children. Recent policy reforms are directed at improving the quality of these schools, by spending more money on them and by providing them with better equipment 
and facilities.

It is noteworthy that the aforementioned factors may explain the differences in educational achievement between immigrants and native Dutch, as well as those between the various immigrant groups. Turks and Moroccans, who lag behind most, have the lowest socio-economic status, the largest "cultural distance", and the least acquaintance with Dutch society and the Dutch language (since Surinam and the Antilles are (former) Dutch colonies with the same educational system as in the Netherlands). Because of their residential distribution, Turks and Moroccans furthermore have the highest concentration in urban schools in the older centres of the largest cities Dutch, which may well be another harmful factor. Cultural aspects and possibly school factors are relevant for the explanation of the arrears of women compared with men among the immigrants.

\subsection{Earnings}

Netherlands' complex tax and subsidy system makes disposable income the best way to compare the earnings of individuals and groups. The 1994 survey of Turks, Moroccans, Surinamese, Antilleans, and native Dutch contains questions on net monthly income. The native Dutch enjoy the highest income level; their average disposable income is 2,040 Dutch guilders $^{1}$ a month. The average minority household has a monthly income of about 80 percent of the Dutch average (Turks (83 percent), Surinamese ( 81 percent), Antilleans (80 percent), and Moroccans (77 percent)). Since the various groups differ widely with respect to family structure, it is interesting to compare average household income per person. Again, the Native Dutch enjoy the highest income level: 1,374 Dutch guilders a month. The average minority household now has a monthly income of not more than about 50 percent of the Dutch average (Antilleans (68 percent), Surinamese (61 percent), Turks (45 percent), and Moroccans (35 percent)).

Labour income is the most important source of income for all groups, be it more

\footnotetext{
${ }^{1} 1$ Dutch guilder $=0.454$ Euro
} 
for the native Dutch than for the immigrant groups. The native Dutch have higher average earnings than the minority groups. Their average net monthly earnings income is 2,489 Dutch guilders, while the Antilleans most closely approximate to the native Dutch with 2,216 Dutch guilders, followed by the Surinamese (2,161 Dutch guilders), the Turks $(1,991$ Dutch guilders), and the Moroccans (1,951 Dutch guilders).

Although there are some differences in the level of support that various groups receive from the government when they are not working (induced by factors such as work history, family size and family structure), minority groups do not appear to be in a disadvantageous position with respect to government assistance. Because minorities are more likely to have larger families and/or be part of a lone-parent household than native Dutch households, they are likely to qualify for relatively generous income support. Nevertheless, the average minority household has only about 50 percent of the Dutch disposable income. This makes it all the more important to explain differences in labour income.

To explore the factors related to earnings differences, the labour income of heads of households working at least 30 hours a week were regressed on educational level, occupation, whether or not the job was a supervisory position, work experience, age, and the length of time in the Netherlands. These factors explain 98 percent of the difference in earnings between native Dutch and Turks, 87 percent of the difference between Surinamese and Dutch, 81 percent of the difference between Antilleans and Dutch, and 78 percent of the difference between Moroccans and Dutch. These findings suggest that differences in human capital and in occupation explain most wage differences.

Kee (1993) investigated the labour market position of male household heads that directly emigrated from Turkey, Morocco, Surinam or the Antilles to the Netherlands. He finds that the education of Turks and Moroccans in their home country has no effect on their wages in the Netherlands. For immigrants from Surinam and the Antilles there is a positive effect of education in the home country on the wage in the Netherlands. Obviously, 
the educational system in the latter two countries has more resemblance to the Dutch educational system. Therefore, skills are more easily transferred. Kee (1993) also finds that the main contributor to differences in wages between immigrants and native Dutch workers is the difference in schooling acquired in the Netherlands. Differences in language abilities are another important determinant of differences in wages. In fact, in wage equations the number of years elapsed since migration has no longer a statistically significant effect once language skills are introduced as explanatory variable. Hartog and Vriend (1990) investigated the labour market position of young Turks and Moroccans that were older than 12 years at the time of arrival in the Netherlands. They find that in terms of earnings functions there is no difference between young Mediterreans and young Dutch.

\subsection{Employment and unemployment}

The labour market participation of ethnic minorities lags behind that of the native Dutch, as is shown in Table 4. This is partly due to differences in age structure, although this factor can hardly explain the large differences between the Turks and Moroccans on the one hand and the native Dutch on the other. Particularly cultural factors explain the remarkably low participation rates of Turkish and Moroccan women. Table 4 indicates that the labour market participation of most of the groups has increased in the period 1990-1997. Labour market participation of native Dutch went up from $60 \%$ to $66 \%$, especially because of a substantial increase in female labour force participation. Labour market participation of Moroccans and Surinamese had an even bigger increase, also because of a strong growth of female labour force participation. Only the Turks had a decline in labour force participation over the period 1990-97.

Given the educational differences mentioned earlier, one would expect certain minority groups to be especially disadvantaged in the labour market. Table 4 shows that unemployment rates (based on registration at the Employment Office) among minorities are several times as high as among the native Dutch. The pattern is clear: Moroccans and Turks 
have the highest unemployment rates, while Antilleans and Surinamese still have higher rates than the native Dutch. As is the case with the unemployment rates of the native Dutch, the unemployment rate of all minority groups declined since 1994. In \%-points the decline for all ethnic minority groups is even larger that that of native Dutch.

In distinct contrast to the situation among the native Dutch, for some minorities men have higher unemployment rates than women. This does not necessarily mean that women have a better labour market position, since there are indications that their lower unemployment rate is related to their acceptance of low-level jobs. In comparison with the situation at the beginning of the 1990s, there is a general decrease of unemployment rates. This is most strikingly the case for Moroccan women, which might be due to the large increase of part-time jobs in the lower segments of the Dutch labour market. Women more than men benefit from this (Dagevos, 1995).

With regard to the duration of unemployment, in 199060 percent of Moroccans and half the Turks and Surinamese had been unemployed for over 2 years. Only a third of the unemployed Antilleans had been unemployed for over 2 years about the same proportion as in the Dutch population at that moment. From the 1994-survey we know that things get worse for the Antilleans (45 percent had been unemployed for over 2 years), while things get better for the Surinamese (the percentage of long-term unemployed went down from 50 to 34). We can only guess at the reasons, although a recent study among Dutch employers revealed that nowadays they judge much more positively about Surinamese compared with other ethnic minorities than they did in the early 1980s. The reason for this is not really clear.

We add that among all ethnic groups, men have a higher percentage of longterm unemployed than women do. This is probably due to "discouragement effects", which may affect women more strongly than men, as a consequence of which women withdraw sooner from the labour market when their unemployment seems lasting.

The disadvantageous position of ethnic minorities in the Dutch labour market 
also appears from data on the workers' position. They more often have temporary instead of permanent jobs compared with the native Dutch; they have less job promotion opportunities and a lower quality of labour. Besides, there is a significant difference in job levels as is shown in Table 6. The pattern is well known: a high percentage of the Turks and Moroccans are on the lower job levels, a low percentage is on the higher levels. The opposite holds true for the native Dutch, while the Surinamese and Antilleans are in between. It comes as no surprise that the data on wages shows much the same pattern (see section 3.1). The pattern described just now applies to women as well as to men, although Moroccan women distinguish themselves by a very high percentage on the lowest job levels. Antillean women most closely approximate to the pattern of the Dutch women.

\subsection{General explanations of ethnic minority unemployment}

The disadvantageous labour market position of ethnic minorities in the Netherlands, and especially their high unemployment rates, have been explained by several factors, from labour demand, to supply characteristics, to institutional aspects. With regard to labour demand, the relevance of general demand factors has been pointed out - such as slackening aggregate demand, and industry and occupation shifts -, as well as the selection practices of Dutch employers. Worker quality and reservation wages, as well as social integration are considered to be relevant supply characteristics. Institutional factors such as labour market policies and the functioning of the Employment Office may also have some influence.

The essence of the aggregate demand explanation is that the supply of minority labour is at the back of an imaginary hiring queue, which implies that when aggregate demand decreases, the minority supply is disproportionately left without a job (see Thurow, 1975). This hypothesis gains empirical support by the fact that there was indeed a slackening demand in the Netherlands, while at the same time ethnic minorities were disproportionately affected by unemployment (Dagevos, 1995). What remains to be 
explained, is why ethnic minorities are at the end of the queue. We will turn to this question when we elaborate on supply characteristics.

The second type of demand-side explanation is a "mismatch"-theory which posits that the minority unemployment problem is not (or not only) that of being last in line, but (also) of being in the wrong place on the labour market. The argument is that ethnic minorities are attached to particular industries, jobs or occupations, and that labour demand in these industries has decreased disproportionately. Analyses of the recent Dutch recessions have shown that some industries and jobs were affected more than others (De Grip, 1987), while minority workers (even the younger ones) were concentrated in most of these market segments (Veenman, 1998). This tallies with the theory, but a full explanation according to this theory requires an account of the immobility of negatively affected minority workers. Cultural factors and tradition may be at work here, but the attachment to certain labour market segments may also be due to little access to other segments. This leads us to a discussion of the selection practices of Dutch employers as well as to the relevance of a "skills mismatch" hypothesis.

Explanations of massive minority unemployment that emphasise the importance of selection practices of Dutch employers, generally point to one of two phenomena: (a) direct racial discrimination, in the sense of Beckers' concept "taste for discrimination", and (b) indirect, unconscious discrimination, in many cases a consequence of ethnocentrism (Veenman, 1990). Whatever the exact reason of the discrimination may be, it is always to the immediate disadvantage of ethnic minorities since it limits access to (attractive) jobs; in other words: it sends ethnic minorities (further) back in the hiring queue. Empirical studies have concentrated much attention on finding out if labour market discrimination actually exists in the Netherlands, and in most cases the answer is in the affirmative (e.g. Bovenkerk, 1979, Bovenkerk et al. 1995, Veenman, 1990, 1995). E.g., Beckers' decomposition method was used to indicate the degree to which discrimination actually determines the unemployment rates of minority groups (Niesing and Veenman, 1990). However, the results 
are inconclusive about the exact degree, although several studies indicate that discrimination may have significant influence on minority unemployment.

The first supply-side explanation for massive minority unemployment emphasises that ethnic minorities generally have inadequate qualifications, and at the same time cling to reservation wages that impede them in finding a job (Niesing, Van Praag and Veenman, 1994). This explanation finds some support in covariant data on educational achievements and language proficiency. In addition, it was shown that the reservation wages of ethnic minorities indeed have a negative influence on their employment opportunities, just as the theory predicts. From this we can conclude that the theory is also significant for the explanation of high minority unemployment, although multivariate analysis indicates that the educational level together with occupational identification, gender, age, and the regional labour market conditions explain only one-third of the difference between unemployment rates of the native Dutch and the respective minority groups (Niesing and Veenman, 1990).

In terms of the Human-Capital theory, the former explanation involves "economic capital". Another supply-side explanation concerns - as the French sociologist Bourdieu puts it - "social capital" and "cultural capital". The essence is that ethnic minorities are not integrated (enough) into Dutch society, which implies (a) that they lack access to important social networks, and (b) that they are too oriented towards their own group and too little towards the Dutch social surroundings. This would impede success on the Dutch labour market. In a study on successful ethnic minorities, it was found that some immigrants who have an advantageous labour market position (high job level, high income), are not at all oriented towards the Dutch social surroundings (Merens and Veenman, 1992). This at least means that social integration is not a necessary condition to find a job. Which, of course, is not to say that social integration might not help in acquiring an advantageous labour market position.

The analysis of minority unemployment in terms of institutional factors 
emphasises context variables rather than sheer labour market phenomena. Labour market policies in particular are discussed. E.g., the disproportionate deterioration of the ethnic minority unemployment in the early 1980s has been explained by the fact that the Employment Office pursued a policy that was highly geared towards the preferences of employers. Although a rational choice (from the point of view of the Employment Office) in times of massive general unemployment, this policy has been to the benefit of those who are first in the hiring queue and to the disadvantage of those at the back.

We underline that the explanations mentioned above do not have the same significance for the different ethnic minority groups in the Netherlands. While using the aggregate demand theory, e.g., we should not expect all ethnic minority groups to be at the same disadvantageous place in the hiring queue: some are better off than others are, because of higher worker quality and/or a higher degree of social integration. At the same time, such supply characteristics influence the selection practices of Dutch employers. This corresponds to the empirical findings that some groups are less wanted than others, mostly because of greater cultural differences (Veenman, 1995). Furthermore, some groups more than others, are attached to particular industries, jobs or occupations, which makes them more vulnerable to a decrease in unemployment in those sectors. And finally, policy measures (such as affirmative action) did not work out the same for the different minority groups. These are all reasons to say that the theories mentioned have a different significance for the explanation of unemployment in various minority groups, and probably also for minority men and women. In other words: these theories are more capable of explaining social diversity than sheer social deprivation among ethnic minorities.

\subsection{Job and Geographical Mobility}

In his dissertation Dagevos (1998) concludes that ethnic minority workers are restricted in their mobility because they have unfavourable labour market characteristics and because they are working in less favourable segments of labour organisations. At the moment the 
available data on job mobility of ethnic minorities are restricted to internal mobility and job stability, which are only two aspects of the more general phenomenon of job mobility. As far as internal mobility is concerned, we confine ourselves to three elements, analysed by Niesing (1993): (a) participation in courses to improve upward internal mobility, (b) actual internal promotions, and (c) expected promotional opportunities.

Contrary to the Surinamese and Antilleans, only a small proportion of the firstgeneration Turks and Moroccans have taken courses to improve their opportunities for internal mobility. In this respect there is not much difference between the Surinamese, the Antilleans, and the native Dutch (see Table 7). It is interesting to note that in the case of the Turks and Moroccans courses were more often given by the company in which they work than in the case of the Surinamese and Antilleans: $76 \%$ and $64 \%$ respectively versus about $40 \%$ for the Surinamese and the Antilleans.

Turks and Moroccans have been promoted less frequently, and also expect fewer promotional opportunities, than the Surinamese and Antilleans who differ less from native Dutch workers in this respect (see Table 8). For ethnic minority workers problems with language proficiency decrease the probability of having been promoted, where as this probability increases with tenure on the job, more education, and age (that is to say: up to middle age). For the native Dutch the probability of having been promoted depends more on personal characteristics than for the ethnic minorities. Therefore, it seems that the latter have been promoted more randomly than the Native Dutch, or due to factors not observed. For the Dutch, but even more so for ethnic minority workers, expectations of having promotional opportunities are affected positively and significantly by having been promoted. These expectations furthermore increase with education and age (again, up to a certain age), while they decrease with tenure.

As far as job stability is concerned, it was found that, on average, the native Dutch have filled a larger number of jobs than the ethnic minorities. Of the male Dutch workers, $40 \%$ have filled more than 3 jobs, while this figure is $24 \%$ for the Surinamese, 
$27 \%$ for the Turks and Antilleans, and 36\% for the Moroccans. This is partly due to the fact that the Dutch have been longer present in the labour market than the ethnic minorities. Those Dutch who have had many jobs usually have a low degree of education, and frequently fill jobs at low job levels. In this sense they are comparable with ethnic minority workers with an unstable jobs.

There is not much information available on geographical mobility of ethnic minorities in the Netherlands. What is known, is that between 1986 and 1990 half of the ethnic minority households moved house versus one-third of the other households. In the period between 1990 and 1994, almost half of the Turkish and Moroccan households moved house and less than $30 \%$ of the other households did. The Surinamese and Antilleans are in-between. The larger number of moves among ethnic minorities is partly due to a larger number of starters on the housing market, which is associated with the on average younger age of ethnic minorities. On the other hand, ethnic minorities are in general less satisfied with their home and therefore more inclined to move house independent of age (Van Dugteren, 1993).

\section{IMMIGRATION AND INTEGRATION POLICIES}

\subsection{Immigration policy}

The Netherlands has one of the highest population densities in the world. Because of this and also to facilitate post-war rebuilding of the country, successive Dutch governments tried to encourage emigration. Nevertheless, the Netherlands became an immigration country because of the influx of immigrant workers in the 1960s and beginning of the 1970s, and also because of the ongoing influx of people from (former) Dutch colonies and, more recently, of political refugees. Furthermore, chain migration in the form of family reunification and family formation among the second generation of immigrants 
adds to the fact that the Netherlands nowadays is an immigration country. Nevertheless, admission to the country is rather limited. Not for Dutch citizens (among them the Antilleans who have Dutch citizenship) and other EU-citizens who are free to move into the Dutch labour market. This freedom is denied to citizens of non-EU-countries. They only have limited possibilities to (temporarily) settle in the Netherlands. Examples of those who have such possibilities are: (a) labour migrants with a temporary labour permit according to the Law on Foreign Workers, (b) minor family members or partners of a native Dutch or legally settled non-Dutch person, (c) political refugees or asylum seekers, and (d) students who mostly come on the basis of bilateral treaties. Asylum seekers do not have access to the Dutch labour market during the period in which Dutch government has to decide on their status.

Nonetheless, the need for immigrant labour did not disappear after the recruitment of workers in Mediterranean countries stopped in 1973. This need for foreign labour was met mainly by immigrants arriving from Surinam in the years immediately before and after the independence of this former colony in 1975 and by immigrants from Turkey and Morocco admitted for family-reunification. The liberal admission of those family members to the labour market is in sharp contrast with the persistent exclusion of asylum seekers from legal employment. The sole form of temporary employment of immigrant workers actively supported by the government was the secondment of Yugoslav workers from the sixties until 1991. Since 1994 a gradual liberalisation of the admission of foreign workers is seasonal jobs can be observed. This policy development coincided and was influenced to a large extent by the liberalisation of the political regime in Poland and, after 1988, in the rest of Eastern Europe (Groenendijk and Hampsink, 1995).

\subsection{The economic effects of immigration}

There are no published studies, which consider the overall effects of emigration and 
immigration on the Dutch economy. ${ }^{2}$ There is a study by the Dutch Centraal Planbureau (Bernardt, 1993) that presents information about the use of the social security system by ethnic minorities and their contribution to the Dutch economy. However, there is no estimate of the overall effects. The Dutch Centraal Planbureau has made different scenarios for the future of the world economy from 1990 to 2015. The economic consequences of immigration depend heavily on the economic developments. In the case of a low growth economy the future will bring unemployment for a lot of immigrants. In the case of a high growth economy immigrants are expected to integrate more into the Dutch labour market. The differences in the labour market position are related to the type of immigrants that are expected to come to the Netherlands. In the low growth scenario most of the immigrants will come from poor countries, while in the high growth scenario most immigrants will come from other rich countries. A study by a consultant group (KPMG, 1994) has similar conclusions with respect to the importance of economic growth on the labour market position of immigrants.

\subsection{Integration policy}

The Dutch policy with respect to immigrants changed over time, as the interpretation of immigration flows changed. Until the mid-1970s immigrants, especially those hired for labour market reasons in the 1960s were expected to return to their home country. It was the arrival of large numbers of Surinamese in the mid-1970s that caused a change in attitude. The initial policy towards immigrants was based on the idea that ethnic minorities should have the opportunity to participate fully in Dutch society but would not be asked to diverge too much from their own culture. This would enable the immigrants to return to their country of origin if they desired. Early 1980s there was a growing awareness that most immigrants did not return to their home country but stayed in the

\footnotetext{
${ }^{2}$ In an internal paper from the Dutch Ministry of Well-being, Health and Culture (Sociaal en Cultureel Planbureau (1988) some estimates are presented with respect to the use by immigrants of government
} 
Netherlands. This shifted the focus of government policy to the integration of immigrants into Dutch society. The main ways to advance this integration were: (1) further the emancipation and participation of ethnic minorities in Dutch society, (2) prevent discrimination, and (3) diminish social and economic differences. Discrimination was legally prohibited, and laws were enacted to give minorities more equality and protection in such areas as suffrage and civil service employment. However, most emphasis was placed on the third goal of diminishing social and economic inequality, and the government became more concerned with ensuring equal access to the benefits of the welfare state. It was in this period that specific measures were chosen to achieve the goals of the integration policy.

In reaction to political developments (a growing support for right-wing movements in the larger cities) and as a consequence of cost-calculations the Dutch government gradually abandoned the strategy of special targeted policies, in favour of emphasising universal, general policies. From that moment on special programmes for minorities were intended to supplement general policy measures. When in the early 1990s the Dutch government realised that migrants not only stayed in the Netherlands, but also kept coming; it started to emphasise policies oriented towards settling in newcomers in the Dutch society. Although these are by their character specific policies, the main idea remained that ethnic minorities had to profit from general policy measures.

Defenders of special programmes point out that the social position of ethnic minorities in the Netherlands is still very tenuous, particularly with regard to their labour market position. As we have shown, the unemployment rates of ethnic minorities are still much higher than those of native Dutch people. Equity of labour market chances is still far away.

budgets on education, unemployment benefits et cetera. However, this exercise was never published. 


\section{CONCLUSIONS}

Ethnic minorities in the Netherlands have a disadvantaged socio-economic position. Data on educational achievements, labour market position, income and housing illustrates their relatively unfavourable situation. Migration characteristics, connected with language problems of immigrants and their restricted knowledge of the receiving society, help explain this situation. This implies that next generations, the children and grandchildren of those who are the true migrants, will have better chances to integrate into Dutch society. Nevertheless, migration characteristics are not the only relevant explanatory variables. As far as the ethnic minority groups themselves are concerned, cultural aspects, less functional social networks and human capital factors add to the explanation. Furthermore, Dutch society seems to contain some strong impediments to the improvement of the socio-economic position of ethnic minorities too. One may wonder whether these impediments have a temporary character, and therefore might be seen as an anomaly in a modern, meritocratic society. In this view Dutch society, being a "young" immigrant country, needs some time to adapt itself to the presence of relatively large numbers of migrants and their descendants.

To take a position in the discussion on the most effective labour market policy, we recall that the most important lesson from Dutch labour market research seems to be that there is no simple, monocausal explanation for the disadvantaged position of ethnic minorities. Demands factors as well as supply factors and institutional variables determine the labour market position of ethnic minorities. In recent years the labour market in the Netherlands has improved substantially. Labour market participation rates are rising and unemployment rates are declining. In this respect ethnic minority groups are not different from native Dutch workers. However for some minority groups participation is still low and for all minority groups unemployment rates are substantially higher that those of native Dutch workers. The policy implication of this finding is that an improvement of the labour market position of ethnic minorities can not be accomplished by general measures alone. 


\section{REFERENCES $S^{3}$}

Bernardt, Y. (1993), Migratie en de allochtone beroepsbevolking van Nederland, 1990-2015, (Migration and the immigrant labour force of the Netherlands, 1990-2015) Research Memorandum 100, Centraal Planbureau, Den Haag.

Bovenkerk, F. (1977), Rasdiscriminatie op de Amsterdamse arbeidsmarkt (Racial discrimination in the Amsterdam labour market), in: Van Hoof, J.J. en A. Martens (eds.), Arbeidsmarkt en ongelijkheid (Labour market and social inequality), Boom, Meppel, 58-76.

Bovenkerk, F., M.J.I. Gras and D. Ramsoedh (1995), Discrimination against migrant workers and ethnic minorities in access to employment in the Netherlands, International Migration Papers 4, Employment Department, International Labour Office, Geneve.

Dagevos, J.M. (1995), De rafelrand van de arbeidsmarkt (The loose ends of the labour market), Boom, Amsterdam.

Dagevos, J.M. (1998), Begrensde mobiliteit; over allochtone werkenden in Nederland (Restricted mobility, working ethnic minorities in the Netherlands), dissertation Erasmus University Rotterdam.

De Grip, A. (1987), Winnaars en verliezers op de arbeidsmarkt 1981-1985 (Winners and losers in the labour market 1981-1985), in: Tijdschrift voor Arbeidsvraagstukken (Journal for labour market issues), 3, 61-69.

Groenendijk, K. and R. Hampsink (1995), Temporary employment of migrants in Europe, University of Nijmegen, Nijmegen.

Hartog, J. and N. Vriend (1989), Post-war international labour mobility: the Netherlands, in: I. Gordon and A.P. Thirlwall (eds.), European factor mobility, trends and consequences, Mcmillan, London, 74-94.

Hartog, J. and N. Vriend (1990), Young mediterraneans in the Dutch labour market: a comparative analysis of allocation and earnings, Oxford Economic Papers, 42, 379-401.

Heijke, J.A.M. (1986), Migratie van Mediterranen: economie en arbeidsmarkt (Migration of Mediterraneans: economy and labour market), Stenfert Kroese, Leiden/Antwerpen.

Heijke, J.A.M. (1987a), The labour market position of migrants in selected European receiving countries, in: The future of migration, OECD, Paris.

Heijke, J.A.M. (1987b), Internationale migratie en bevolkingsstructuur (International migration and

\footnotetext{
${ }^{3}$ In parentheses the translation of the Dutch titles.
} 
the structure of population), in: Demografische veranderingen en economische ontwikkelingen (Demographic changes and economic development), Preadviezen van de Koninklijke Nederlandse Vereniging voor de Staatshuishoudkunde (Pre-advises of the Royal Dutch Society for Economics) Stenfert Kroese, Leiden/Antwerpen, 125-156.

Kee, P. (1993), The economic status of male immigrants in the Netherlands, dissertation University of Amsterdam.

KPMG/Bureau voor Economische Argumentatie (1994) De economische betekenis van minderheden voor de arbeidsmarkt (The economic contribution of minorities to the labour market), Hoofddorp.

Martens, E.P., Th. Roelandt and J. Veenman (1991), Ethnic minority children in Dutch education: ethnic stratification, social class and migration, in: the Netherlands'Journal of Social Sciences, 27, 92-108.

Merens, J.G.F. and J. Veenman (1992), Succes en falen bij allochtonen (Success and failure among ethnic minorities), Organisation for Strategic Labour Market Research (OSA), The Hague.

Nickell, S. and J.C. van Ours (1999), The Netherlands and the United Kingdom: A European Unemployment Miracle?, Economic Policy, forthcoming.

Niesing, W. (1993), The labor market position of ethnic minorities in the Netherlands, dissertation Erasmus University Rotterdam, Rotterdam.

Niesing, W., B.M.S. van Praag and J. Veenman (1994), The unemployment of ethnic minority groups in the Netherlands, Journal of Econometrics, 61, 173-196.

Niesing, W. and J. Veenman (1990), Achterstand en achterstelling op de arbeidsmarkt (Deficits and discrimination in the labour market), in: Veenman, J. (ed.), Ver van Huis. Achterstand en achterstelling bij allochtonen (Far from Home, deficits among and discrimination towards ethnic minorities), Wolters-Noordhoff, Groningen, 41-69.

Sociaal en Cultureel Planbureau (1988), Kosten van de aanwezigheid van etnische groepen in de periode 1987-2000 (Costs of the presence of ethnic groups in the period 1987-2000), Internal paper Ministry of Well-being, Health and Culture, Rijswijk.

Thurow, L.C. (1975), Generating inequality, Basic Books, New York.

Van Dugteren, F. (1993), Woonsituatie minderheden, Achtergronden en ontwikkelingen 1982-1990 en vooruitzichten voor de jaren negentig (Housing conditions among ethnic minorities, Backgrounds and developments 1982-1990 and prospects for the Nineties), VUGA, Rijswijk. 
Veenman, J. (1990), De arbeidsmarktpositie van allochtonen in Nederland, in het bijzonder van Molukkers (The labour market position of ethnic minorities, particularly Moluccans), WoltersNoordhoff, Groningen.

Veenman, J. (1995), Onbekend maakt onbemind, Selectie van allochtonen op de arbeidsmarkt (Unknown and unloved, The selection of ethnic minorities in the labour market), Van Gorcum, Assen.

Veenman, J. (1998), Buitenspel, Over langdurige werkloosheid onder etnische minderheden (Offside, A treatise on long-term unemployment among ethnic minorities), Van Gorcum, Assen. 
Table 1 Population growth and migration in the Netherlands; 1900-1995 (1000/year)

$\begin{array}{lccll} & 1900-1940 & 1946-1963 & 1964-1975 & 1976-1995 \\ \text { Births } & 174 & 241 & 225 & 184 \\ \text { Deaths } & 80 & 83 & 106 & 123 \\ \text { Birth surplus } & 94 & 158 & 119 & 61 \\ & & & & \\ \text { Immigration } & 39 & 53 & 83 & 94 \\ \text { Emigration } & 38 & 60 & 60 & 59 \\ \text { Immigration surplus } & 1 & -7 & 23 & 35 \\ \text { Population growth } & 95 & 151 & 142 & 96 \\ \text { Migration } & 406 & 474 & 637 & 580\end{array}$

Source: Netherlands Central Bureau of Statistics

Table 2 Unemployment rates (registered unemployed as \% of labour force) and nonemployment rates (employed as \% of working age population)

\begin{tabular}{lcccccc} 
& \multicolumn{3}{c}{ Unemployment rates } & \multicolumn{3}{c}{ Non-employment rates } \\
& 1990 & 1995 & 1998 & 1990 & 1995 & 1997 \\
Total & & & & & & \\
Male & 5.9 & 7.0 & 4.0 & 44.8 & 42.2 & 39.4 \\
Female & 5.4 & 6.4 & 3.5 & 28.9 & 28.4 & 26.2 \\
& 6.8 & 8.1 & 4.7 & 61.2 & 56.5 & 53.0
\end{tabular}

Source: Netherlands Central Bureau of Statistics

Table 3 Educational attainment of pupils by immigrant status (19-30 years; \% of total) ${ }^{\text {a) }}$

\begin{tabular}{|c|c|c|c|c|c|c|c|c|}
\hline & Primary & Seco & dary & Inter & ediate & Hig & - University & Total \\
\hline & & Voc & Gen & Voc & Gen & Voc & & \\
\hline Turks & 15 & 22 & 34 & 11 & 12 & 4 & 3 & 100 \\
\hline Moroccans & 17 & 22 & 28 & 16 & 12 & 3 & 2 & 100 \\
\hline Surinamese & 8 & 16 & 18 & 17 & 20 & 8 & 12 & 100 \\
\hline Antilleans & 8 & 15 & 14 & 14 & 8 & 18 & 23 & 100 \\
\hline Native Dutch & 7 & 6 & 13 & 9 & 21 & 17 & 28 & 100 \\
\hline
\end{tabular}


Table 4 Labour market participation by immigrant status (15-65 years; participants as a percentage of population)

\begin{tabular}{llllllllll} 
& Total & \multicolumn{3}{c}{ Males } & \multicolumn{5}{c}{ Females } \\
& 1990 & 1994 & 1997 & 1990 & 1994 & 1997 & 1990 & 1994 & 1997 \\
& & & & & & & & & \\
Turks & 48 & 42 & 45 & 65 & 59 & 64 & 28 & 23 & 24 \\
Moroccans & 37 & 40 & 44 & 54 & 54 & 58 & 14 & 23 & 24 \\
Surinamese & 54 & 60 & 66 & 61 & 68 & 71 & 46 & 53 & 61 \\
Antilleans & 55 & 56 & 57 & 64 & 72 & 67 & 48 & 43 & 49 \\
Native Dutch & 60 & 63 & 66 & 75 & 76 & 77 & 44 & 48 & 52
\end{tabular}

Source: Netherlands Central Bureau of Statistics

Table 5 Registered unemployment by immigrant status (15-65 years; registered unemployed as a percentage of total labour force)

\begin{tabular}{llllllllll} 
& Total & \multicolumn{3}{c}{ Males } & \multicolumn{5}{c}{ Females } \\
& 1990 & 1994 & 1997 & 1990 & 1994 & 1997 & 1990 & 1994 & 1997 \\
& & & & & & & & & \\
Turks & 34 & 36 & 31 & 36 & 36 & 30 & 28 & 36 & 36 \\
Moroccans & 35 & 31 & 22 & 21 & 22 & 21 & 39 & 20 & 15 \\
Surinamese & 18 & 18 & 13 & 19 & 19 & 12 & 16 & 17 & 14 \\
Antilleans & 22 & 30 & 24 & 19 & 28 & 16 & 26 & 33 & 31 \\
Native Dutch & 5 & 6 & 4 & 4 & 6 & 4 & 6 & 7 & 6
\end{tabular}

Source: Netherlands Central Bureau of Statistics

Table 6 Job levels of employed workers by immigrant status (15-65 years)

$\begin{array}{lllllll} & \begin{array}{l}\text { Very simple } \\ \text { Tasks }\end{array} & \begin{array}{l}\text { Simple Medium } \\ \text { tasks }\end{array} & \begin{array}{l}\text { High level } \\ \text { job }\end{array} & \begin{array}{l}\text { Scientific } \\ \text { activities }\end{array} & \text { Total } \\ \text { Turks } & 36 & 33 & 25 & 6 & 0 & 100 \\ \text { Moroccans } & 40 & 30 & 25 & 5 & 1 & 100 \\ \text { Surinamese } & 19 & 35 & 34 & 11 & 2 & 100 \\ \text { Antilleans } & 16 & 24 & 37 & 19 & 4 & 100 \\ \text { Native Dutch } & 7 & 27 & 35 & 24 & 7 & 100\end{array}$

Source: ISEO, Survey social position ethnic minorities, 1994 
Table 7 Workers who have taken courses to improve internal mobility by immigrant status (\% of employed heads of households)

Males Females

$\begin{array}{lll}\text { Turks } & 21 & \\ \text { Moroccans } & 14 & \\ \text { Surinamese } & 57 & 51 \\ \text { Antilleans } & 66 & 43 \\ \text { Native Dutch } & 57 & 34\end{array}$

Source: ISEO, Survey social position ethnic minorities, 1994

Table 8 Promotions and promotion opportunities by immigrant status (\% of employed heads of households)

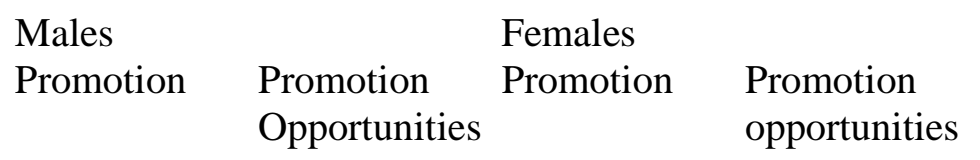

$\begin{array}{lllll}\text { Turks } & 22 & 20 & \cdot & \cdot \\ \text { Moroccans } & 20 & 23 & \cdot & . \\ \text { Surinamese } & 52 & 58 & 23 & 39 \\ \text { Antilleans } & 44 & 51 & 38 & 55 \\ \text { Native Dutch } & 57 & 50 & 42 & 52\end{array}$

Source: ISEO, Survey social position ethnic minorities, 1994 
Figure 1 Birth-surplus in the Netherlands, 1900-1997 (1000)

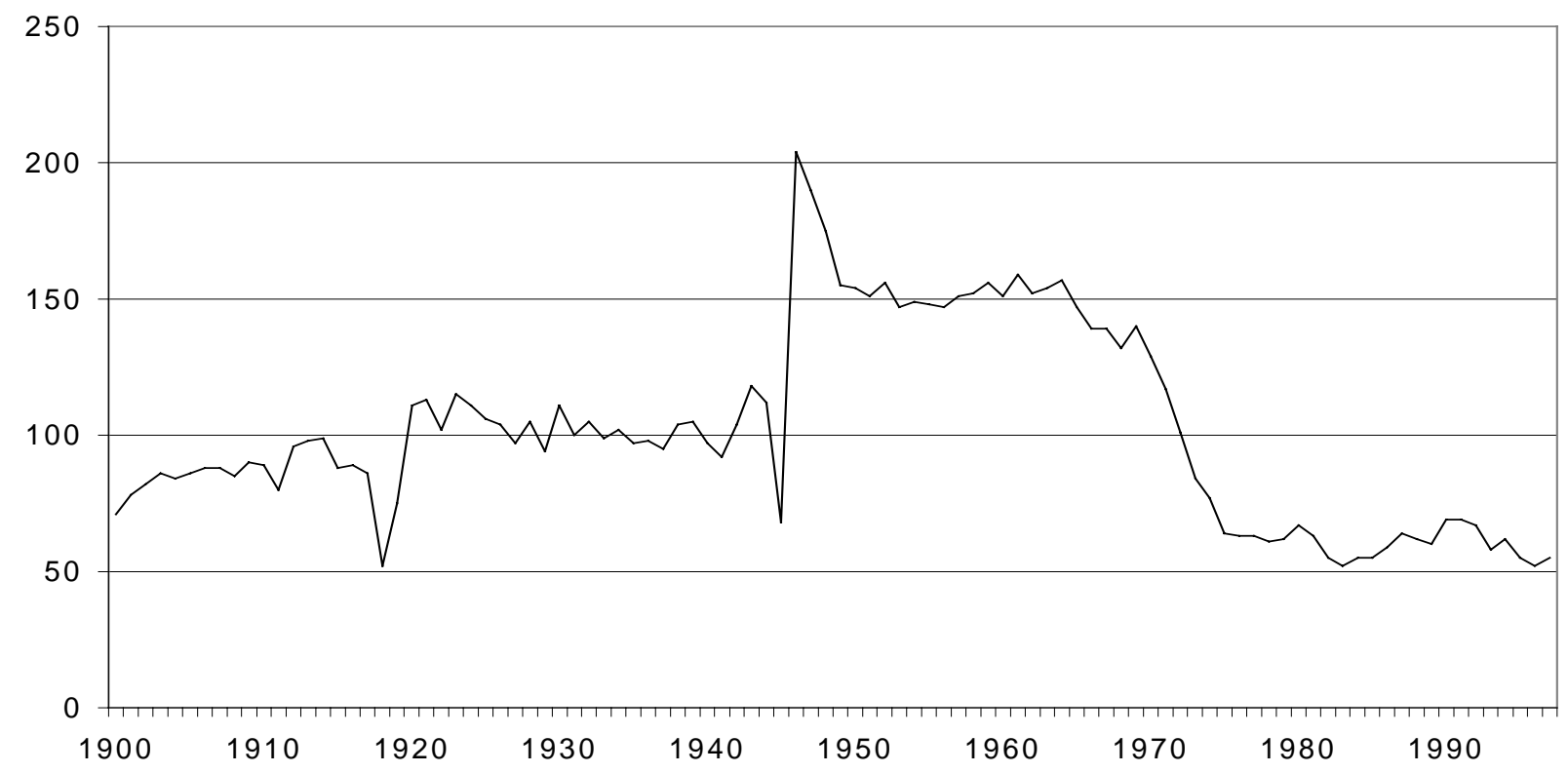

Source: Netherlands Central Bureau of Statistics

Figure 2 Immigration surplus in the Netherlands, 1900-1997 (1000)

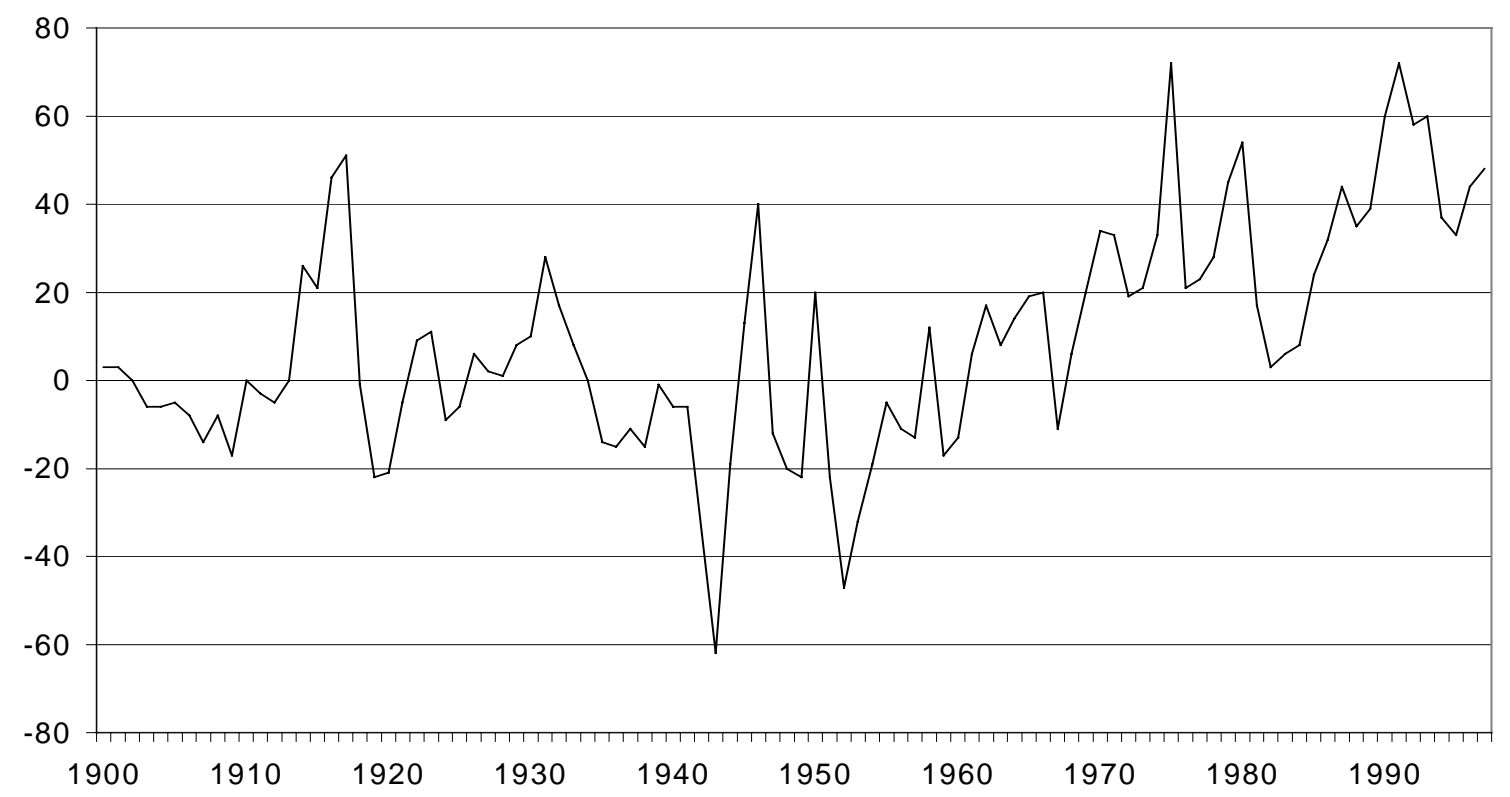

Source: Netherlands Central Bureau of Statistics 
Figure 3 Immigration from former Dutch colonies, 1945-1996 (1000)

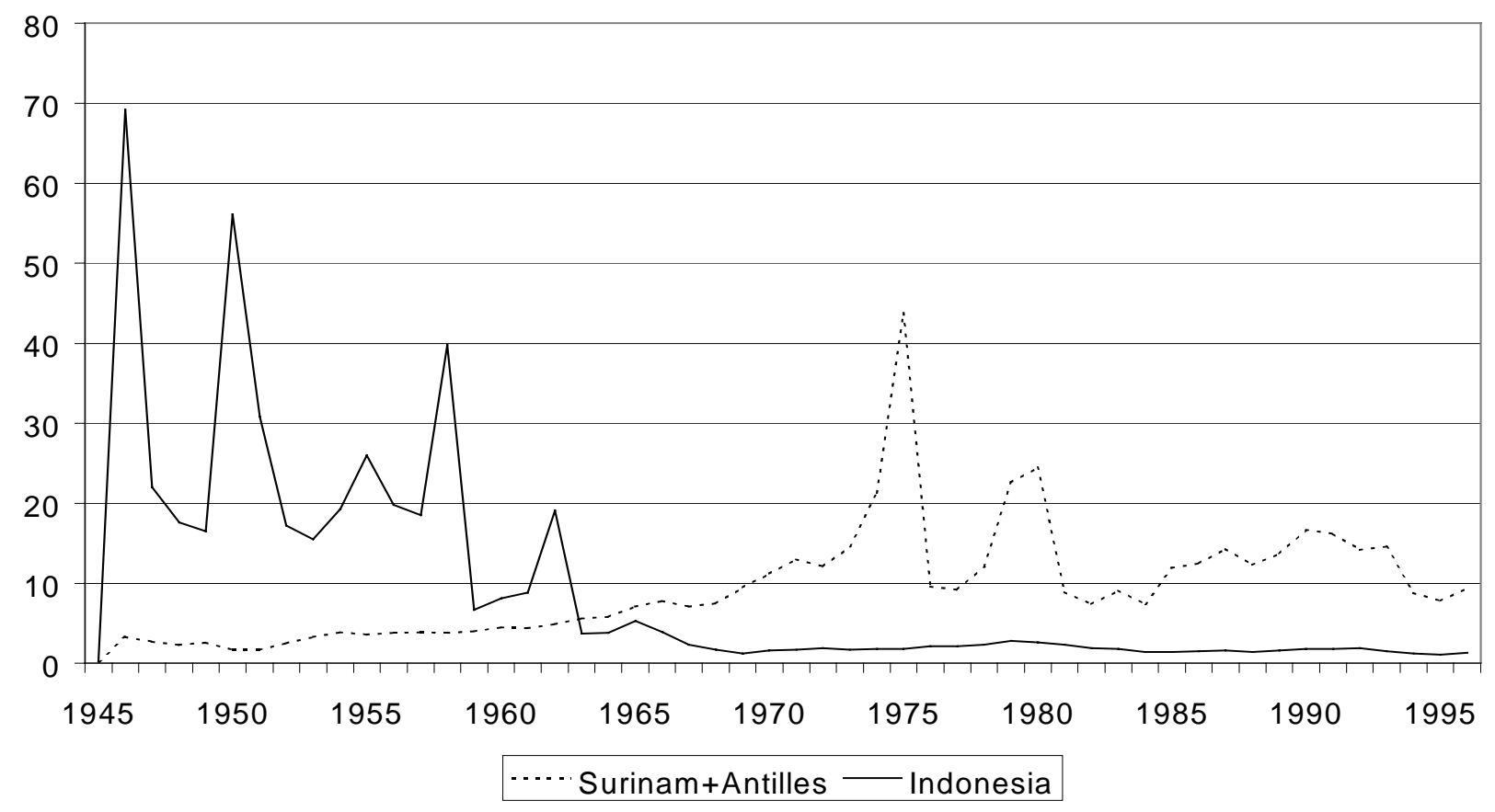

Source: Netherlands Central Bureau of Statistics

Figure 4 Immigration from Morocco and Turkey, 1945-1996 (1000)

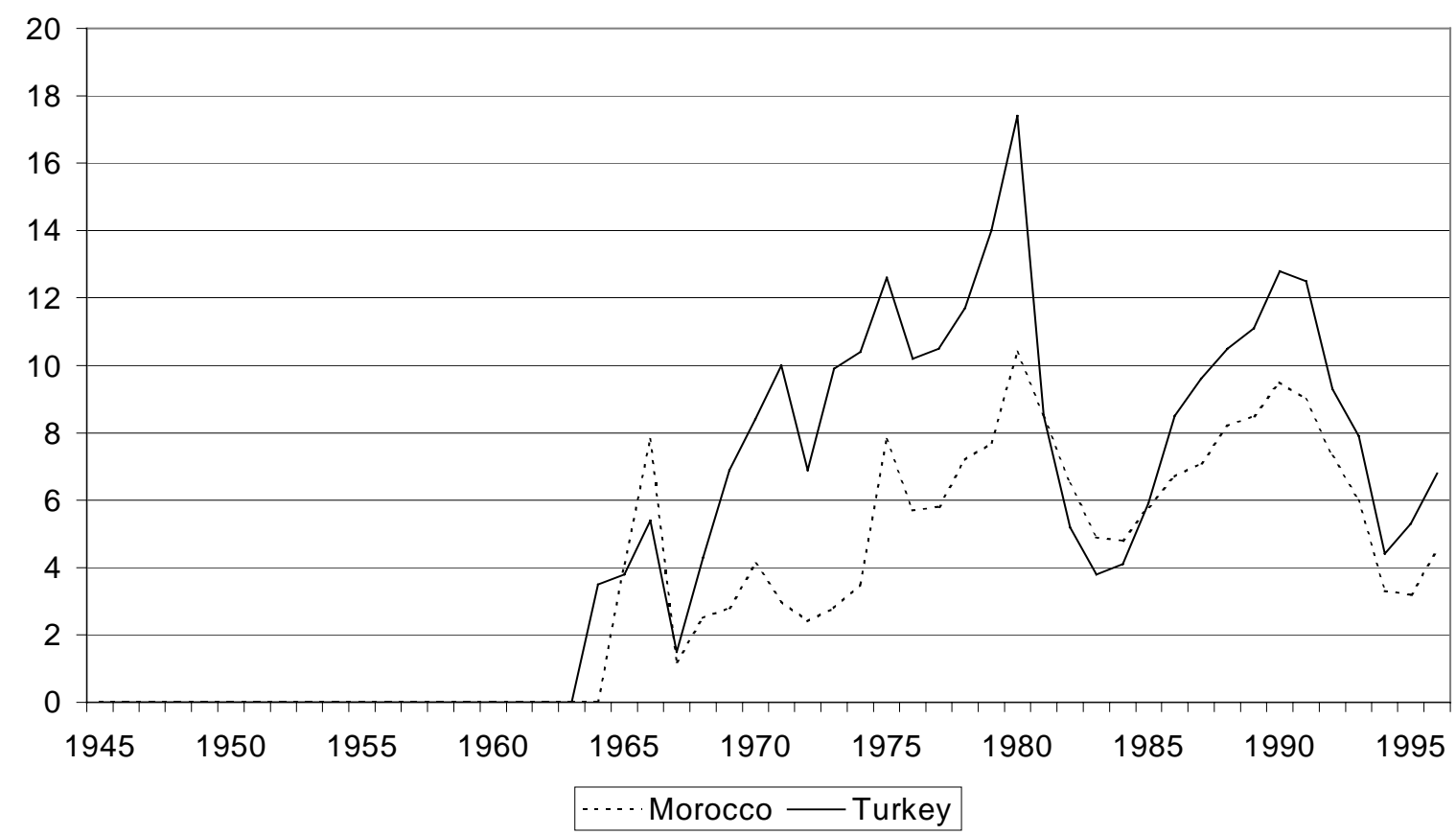

Source: Netherlands Central Bureau of Statistics 